\title{
Sol-gel microsphere pelletization: A powder-free advanced process for fabrication of ceramic nuclear fuel pellets
}

\author{
C GANGULY \\ Radiometallurgy Division, Bhabha Atomic Research Centre, Bombay 400085, India
}

\begin{abstract}
Hydrated gel-microspheres of $\mathrm{U}, \mathrm{Pu}, \mathrm{Th}$ oxide or oxide plus carbon mixture of diameter $400-800 \mu$ were prepared by ammonia gelation processes. They were dried and subjected to suitable treatment for obtaining free-flowing oxide, carbide or nitride microspheres of diameter $200-400 \mu$ suitable for direct pelletization and sintering. The oxide, carbide and nitride pellets were, in general, sintered at high temperature in $\mathrm{Ar}+8 \% \mathrm{H}_{2}$. However, for $\mathrm{UO}_{2}$ and $(\mathrm{U}, \mathrm{Pu}) \mathrm{O}_{2}$ pellets low temperature $\left(1200^{\circ} \mathrm{C}\right)$, short duration $(\mathrm{l} \mathrm{h})$ oxidative $\left(\mathrm{CO}_{2}\right.$ or $\mathrm{N}_{2}+$ air) sintering (LTS) was also successful, thereby reducing electrical energy and gas consumption during sintering. Thus, the combined SGMP-LTS process simultaneously minimized "radiotoxic dust hazard" and fuel fabrication cost in case of $\mathrm{UO}_{2}$ and $(\mathrm{U}, \mathrm{Pu}) \mathrm{O}_{2}$ pellets.
\end{abstract}

Keywords. Sol-gel pelletization; ceramic nuclear fuel pellets.

\section{Introduction}

Nuclear power reactors utilize fission heat energy for generation of electricity and use as fuels, judicious combinations of fissile ${ }^{235} \mathrm{U},{ }^{239} \mathrm{Pu}$ and ${ }^{233} \mathrm{U}$ and fertile $\mathrm{U}^{238}$ and $\mathrm{Th}^{232}$ isotopes. The fuel is in the form of oxide, monocarbide or mononitride. Ceramic nuclear fuels are mostly fabricated in small cylindrical pellets (diameter 4-15 mm height to diameter ratio: $0 \cdot 8-1 \cdot 2$ ). The fuel pellets are stacked inside metallic cladding tube and encapsulated to form "fuel pin".

Table 1 summarizes the conventional and advanced fuels for water-cooled thermal reactors and liquid metal-cooled fast breeder reactors (LMFBR). Light water reactors (LWR) and pressurized heavy water reactors (PHWR) contribute to more than $90 \%$ of the nuclear reactors today and use zircaloy clad high density ( $\geqslant 94 \%$ T.D.) $\mathrm{UO}_{2}$ fuel. Natural uranium $\left(0.7 \%{ }^{235} \mathrm{U}+99.3 \%{ }^{238} \mathrm{U}\right)$ and 1.5 to $3 \%{ }^{235} \mathrm{U}$ enriched uranium are used in PHWR and LWR respectively. These water-cooled power reactors, apart from generating electricity, produce fissile ${ }^{239} \mathrm{Pu}$ as byproduct which is utilized most efficiently as fuel in LMFBRs which are likely to be commercialized during the next two to three decades. The Pu content in LMFBR fuel is in the range of $15-20 \%$. Mixed uranium oxide is the reference fuel for LMFBR all over the world but (U, Pu) $\mathrm{C}$ and $(\mathrm{U}, \mathrm{Pu}) \mathrm{N}$ have been recognized as advanced LMFBR fuels on the basis of their better thermal conductivity and higher breeding ratio. Since the LMFBR programme has been delayed all over the world, several countries have started interim utilization of plutonium by-product in LWR as (U, $\mathrm{Pu}) \mathrm{O}_{2}$ fuel containing up to $8 \% \mathrm{Pu}$. (U, Pu) $\mathrm{O}_{2}$ and $(\mathrm{Th}, \mathrm{Pu}) \mathrm{O}_{2}$ fuels containing up to $4 \% \mathrm{Pu}$ could also be used in PHWR. The fissile ${ }^{233} \mathrm{U}$ produced from $\mathrm{Th}$ could be very effectively recycled as self-sustaining $\left(\mathrm{Th},{ }^{233} \mathrm{U}\right) \mathrm{O}_{2}$ fuel in PHWR. 
Table 1. Conventional and advanced nuclear fuel pellets for commercial $L W R$, PHWR and LMFBR.

\begin{tabular}{|c|c|c|}
\hline Reactor & Conventional fuel & Advanced fuel \\
\hline $\begin{array}{l}\text { LWR } \\
\text { (PWR and BWR) }\end{array}$ & $\begin{array}{l}\text { High density } \mathrm{UO}_{2} \\
\left(1.5-3 \% \text { enriched }{ }^{235} \mathrm{U}\right)\end{array}$ & $\begin{array}{l}\text { High density }(\mathrm{U}, \mathrm{Pu}) \mathrm{O}_{2} \\
(\leqslant 8 \% \mathrm{Pu})\end{array}$ \\
\hline PHWR & $\begin{array}{l}\text { High density } \mathrm{UO}_{2} \\
\text { (Natural U) }\end{array}$ & $\begin{array}{l}\text { High density } \mathrm{UO}_{2} \\
\text { (S.E.U. or R.E.U.) } \\
\text { High density (U, Pu)O } \\
\text { ( } \leqslant 4 \% \text { Pu) } \\
\left.\text { High density (Th, }{ }^{233} \mathrm{U}\right) \mathrm{O}_{2} \\
\left(\leqslant 4 \%{ }^{233} \mathrm{U}\right)\end{array}$ \\
\hline LMFBR & $\begin{array}{l}\text { Low density }(\mathrm{U}, \mathrm{Pu}) \mathrm{O}_{2} \\
(\sim 15 \% \mathrm{Pu})\end{array}$ & $\begin{array}{l}\text { Low density }(\mathrm{U}, \mathrm{Pu}) \mathrm{C} \text { and }(\mathrm{U}, \mathrm{Pu}) \mathrm{N} \\
\quad(\sim 15 \% \mathrm{Pu})\end{array}$ \\
\hline
\end{tabular}

\subsection{Radiation hazards in fabrication of nuclear fuels}

Naturally occurring fissile ${ }^{235} \mathrm{U}$ and fertile ${ }^{238} \mathrm{U}$ and ${ }^{232} \mathrm{Th}$, though radioactive, are relatively less hazardous $\alpha$-emitters with very low specific activity. Hence, natural or enriched $\mathrm{UO}_{2}$ fuel pellets are fabricated and handled in well-ventilated and controlled areas, keeping radioactive aerosols to a minimum. On the other hand, the man-made fissile isotopes ${ }^{239} \mathrm{Pu}$ and ${ }^{233} \mathrm{U}$ have several orders of higher specific $\alpha$ radioactivity, are highly radiotoxic and are associated with high $\beta-\gamma$ and neutron radiations due to the presence of other highly radioactive isotopes in them. For example, ${ }^{233} \mathrm{U}$ always contains ${ }^{232} \mathrm{U}$, in traces, which has strong $\gamma$ emitting daughter products. Likewise, ${ }^{239} \mathrm{Pu}$ obtained from spent power reactor fuel, always contains significant percentage of ${ }^{240} \mathrm{Pu},{ }^{241} \mathrm{Pu},{ }^{242} \mathrm{Pu}$ and ${ }^{238} \mathrm{Pu}$ which emit neutron and $\gamma$ radiations. Hence, fabrication and handling of $\mathrm{Pu}$ and ${ }^{233} \mathrm{U}$-bearing materials are always carried out inside leak-tight glove boxes, in well-ventilated and controlled areas, often with adequate $\beta-\gamma$ and neutron shieldings. Since carbide and nitride are highly susceptible to oxidation and hydrolysis and are pyrophoric in powder form, high purity inert atmosphere $\left(\mathrm{N}_{2}\right.$ or $\left.\mathrm{Ar}\right)$ is used as cover gas in glove boxes. A high degree of remotization and automation is also necessary for fabrication of $\mathrm{Pu}$ and ${ }^{233} \mathrm{U}$ bearing fuels in order to keep personnel exposure to radiation as low as can be reasonably achieved within acceptable iimits (presently $0.05 \mathrm{~Sv}$ per year to be progressively reduced to 0.02 Sv by 1995).

\subsection{Powder-pellet and SGMP processes}

Ceramic nuclear fuel pellets are conventionally fabricated by powder metallurgy route starting with fine $(<1 \mu) \mathrm{UO}_{2}, \mathrm{PuO}_{2}$ and $\mathrm{ThO}_{2}$ powders (Ganguly 1990). $\mathrm{UO}_{2}$ powder is industrially prepared either by (i) wet chemical routes namely ammonium diurante $(A D U)$ and ammonium uranium carbonate (AUC) processes starting with $\mathrm{UF}_{6}$ gas or uranyl nitrate hexa hydrate solutions or by (ii) integrated dry route (IDR) using $\mathrm{UF}_{6}$ gas as feed material. $\mathrm{ThO}_{2}$ and $\mathrm{PuO}_{2}$ powders are prepared by calcination of 
Th-oxalate and $\mathrm{Pu}$-oxalate respectively which are formed by addition of oxalic acid to nitrate solution of thorium or plutonium. Since $\mathrm{UO}_{2}, \mathrm{PuO}_{2}$ and $\mathrm{ThO}_{2}$ are isostructural ( $\mathrm{FCC}, \mathrm{CaF}_{2}$ type), completely solid soluble and have very similar thermodynamic properties, their fabrication processes are nearly identical. For fabrication of oxide and mixed oxide fuel pellets, the major steps are milling (co-milling for mixed oxides), cold-pelletization and high temperature $\left(1650-1700^{\circ} \mathrm{C}\right)$ sintering in $\mathrm{N}_{2} / \mathrm{Ar}+\mathrm{H}_{2}$ atmosphere. For preparation of $(\mathrm{U}, \mathrm{Pu}) \mathrm{C}$ and $(\mathrm{U}, \mathrm{Pu}) \mathrm{N}$ pellets, $\mathrm{UO}_{2}, \mathrm{PuO}_{2}$ and graphite powders are co-milled, tableted and subjected to carbothermic synthesis at $1500-1600^{\circ} \mathrm{C}$ in vacuum and flowing nitrogen for preparation of monocarbide and mononitride clinkers respectively. Next, these clinkers are crushed, milled, coldpelletized and sintered to obtain $(\mathrm{U}, \mathrm{Pu}) \mathrm{C}$ and $(\mathrm{U}, \mathrm{Pu}) \mathrm{N}$ fuel pellets (Ganguly 1980; Matzke 1986). UC, UN, PuC and $\mathrm{PuN}$ are isostructural (FCC, $\mathrm{NaCl}$ type), completely solid soluble and have similar thermodynamic and thermophysical properties.

The powder-pellet route involves generation and handling of fine powder or particles $(<1 \mu)$ of the fuel and is hence associated with the problem of radiotoxic dust hazard and fire hazard (applicable for carbide and nitride powders). Further, the fine powders are not free-flowing and pose problems in remote and automated fabrication. Microhomogeneity of fissile species in mixed oxide is not fully obtained since the oxide powders are mechanically mixed.

The alternative sol-gel microsphere pelletization (SGMP) process uses dust-free, free-flowing and coarse (100-2000 $\mu$ ) hydrated gel-microspheres of oxide or oxide + carbon mixture as starting materials for pellet making. Table 2 summarizes the popular sol-gel routes (Ferguson et al 1961; IAEA 1974). Sol-gel process, based on dehydration reaction, was first introduced by the Oak Ridge National Laboratory (ORNL), USA (Ferguson et al 1961), in the early 1960s for preparation of gel-microspheres of $\mathrm{UO}_{3}$. However, the ORNL process is no longer in vogue and has been replaced by the more recent ammonia gelation processes developed in Europe which cause rapid gelation of droplets of sols or solutions of the nitrates of $\mathrm{U}, \mathrm{Th}$ or Pu either externally by ammonia gas and ammonium hydroxide or internally by an added ammonia generator such as hexa methylene tetra amine (HMTA).

External gelation of thorium (EGT) (Ringel and Zimmer 1979) and uranium (EGU) (Naefe and Zimmer 1979) processes of KfK (Nuclear Research Centre), Juelich, West Germany were primarily developed in the early 1980 s for preparation of very high

Table 2. Principal sol-gel routes for preparation of hydrated gel-microspheres of oxides of $\mathrm{U}, \mathrm{Th}$ and $\mathrm{Pu}$.

\begin{tabular}{lll}
\hline Process & Materials prepared & Laboratory/country \\
\hline Dehydration & $(\mathrm{Th}, \mathrm{U}) \mathrm{O}_{2}$ and $\mathrm{PuO}_{2}$ & ORNL, USA \\
External gelation & $\mathrm{ThO}_{2}, \mathrm{UO}_{2}$ and $(\mathrm{Th}, \mathrm{U}) \mathrm{O}_{2}$ & $\mathrm{NUKEM}, \mathrm{FRG}$ \\
External gelation & $\mathrm{UO}_{2}$ and $\mathrm{UO}_{2}-20 \% \mathrm{PuO}_{2}$ & SNAM, Italy \\
External gelation of thorium (EGT) & $\mathrm{ThO}_{2}$ and (Th, $\mathrm{UO}_{2}$ & KfA, FRG \\
External gelation of uranium (EGU) & $\mathrm{UO}_{2}$ & KfA, FRG \\
& & \\
Internal gelation & $\mathrm{UO}_{2}$ and $\mathrm{UO}_{2}-\mathrm{PuO}_{2}$ & KEMA, Netherland \\
Internal gelation & $\mathrm{UO}_{2}, \mathrm{ThO}_{2}$ and $\left(\mathrm{U}, \mathrm{Th}_{2} \mathrm{O}_{2}\right.$ & KfA, FRG \\
Internal gelation of uranium (IGU) & $\mathrm{UO}_{2}$ and $\mathrm{UO}_{2}-\mathrm{PuO}_{2}$. & BARC, India \\
\hline
\end{tabular}


density ( $\geqslant 98 \%$ T.D.) $\mathrm{ThO}_{2}, \mathrm{UO}_{2},(\mathrm{Th}, \mathrm{U}) \mathrm{O}_{2}, \mathrm{UC}_{2}$ and ( $\left.\mathrm{Th}, \mathrm{U}\right) \mathrm{C}_{2}$ microspheres of diameter $\sim 500 \mu$ for fabrication of coated fuel particles for high temperature gas-cooled reactors. The EGT process is suitable for preparing hydrated gel-microspheres of $\mathrm{ThO}_{2}$ and also $\mathrm{ThO}_{2}+\mathrm{UO}_{3}$ containing at least up to $20 \% \mathrm{UO}_{3}$. The internal gelation of uranium (IGU) process (Vaidya et al 1987) of BARC on the other hand was developed for preparation of high density ( $\geqslant 98 \%$ T.D.) microspheres of $\mathrm{UO}_{2}$ and $(\mathrm{U}, \mathrm{Pu}) \mathrm{O}_{2}$ of size fractions $1000 \mu$ and $100 \mu$ for "vibratory compaction" of fuel pins.

The gel-microsphere are: (a) calcined in controlled atmosphere at $700-800^{\circ} \mathrm{C}$ to obtain oxide microspheres or (b) subjected to carbothermic synthesis in vacuum and flowing nitrogen for producing monocarbide and mononitride microspheres respectively. The oxide, monocarbide and mononitride fuel microspheres thus formed are directly pelletized and sintered. The SGMP process is relatively new and has not been tried so far anywhere on an industrial scale. Figure 1 shows the major process

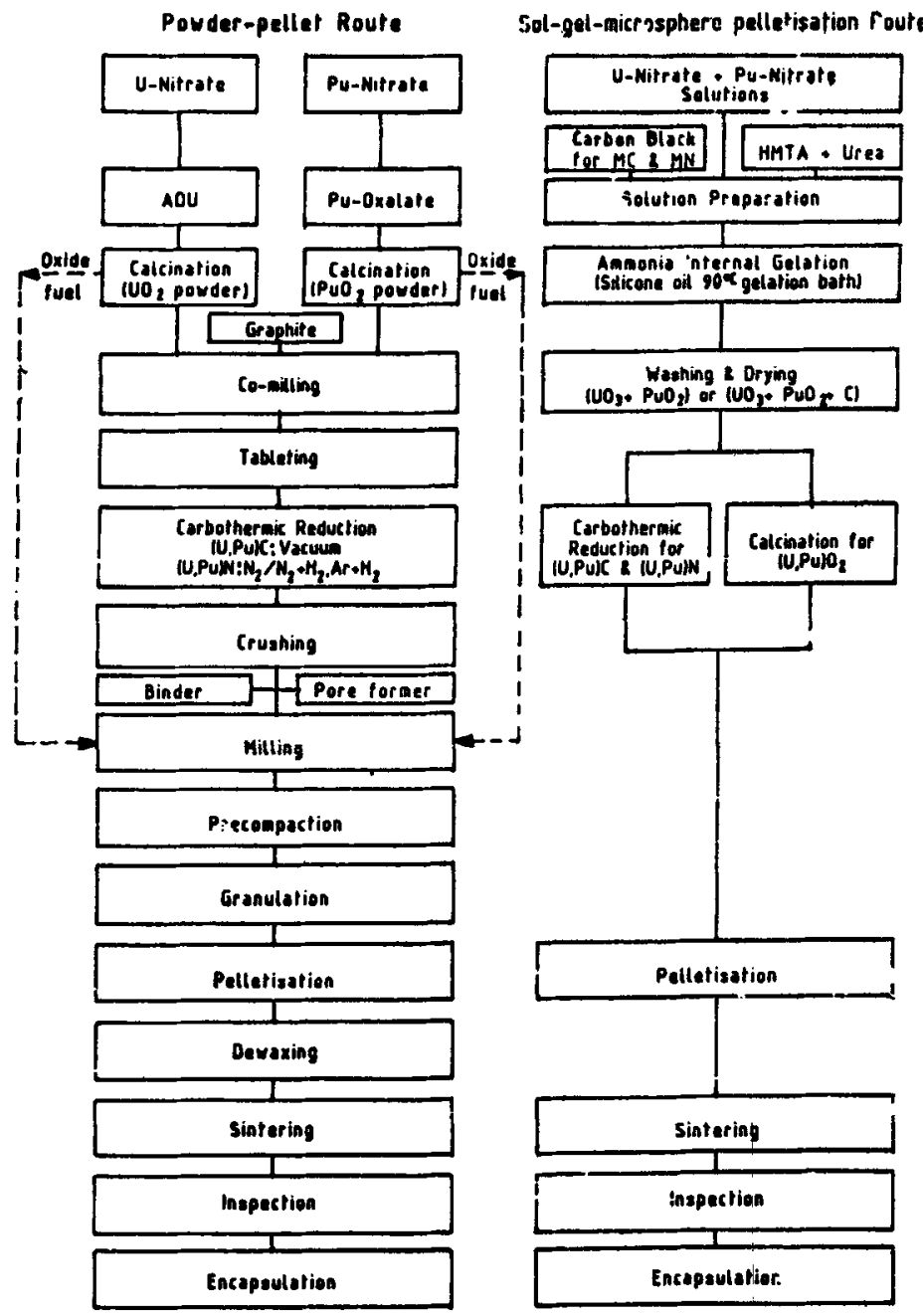

Figure 1. Powder-pellet and SGMP routes for fabrication of $(\mathrm{U}, \mathrm{Pu}) \mathrm{O}_{2},(\mathrm{U}, \mathrm{Pu}) \mathrm{C}$ and $(\mathrm{U}, \mathrm{Pu}) \mathrm{N}$ pellets. 
steps in SGMP and "powder-pellet" routes. The advantages of SGMP process are as follows:

(i) generation and handling of fine powder of fuel are avoided, thus minimizing "radiotoxic dust hazard", "fire hazard" (carbide and nitride powder) and the frequency of decontamination of equipment and inner surfaces of glove boxes or hot cells in $\mathrm{Pu}$ and ${ }^{233} \mathrm{U}$ fuel fabrication facility;

(ii) "dust-free" and "free-flowing" microspheres facilitate remote fabrication and automation, thus minimizing man sievert (radiation dose) in fuel production plant;

(iii) lesser number of process steps are involved compared to that of "powder-pellet" route, particularly for fabrication of carbide and nitride fuel pellets as shown in figure 1; (iv) excellent microhomogeneity of fissile and fertile isotopes is ensured in mixed oxide, carbide and nitride fuel pellets since nitrate solutions of $\mathrm{U}, \mathrm{Th}$ and $\mathrm{Pu}$ are mixed in the liquid stage.

\subsection{Objective of present paper}

The present paper summarizes the author's research experience during 1984-1992 in BARC, Bombay, India and in KfK (Nuclear Research Centre), Juelich, West Germany for developing SGMP process for fabrication of: (i) $\mathrm{UO}_{2},(\mathrm{U}, \mathrm{Pu}) \mathrm{O}_{2}$ and $(\mathrm{Th}, \mathrm{U}) \mathrm{O}_{2}$ fuel pellets containing less than $4 \%$ fissile material for LWRs and PHWRs and (ii) $(\mathrm{U}, \mathrm{Pu}) \mathrm{O}_{2},(\mathrm{U}, \mathrm{Pu}) \mathrm{C}$ and $(\mathrm{U}, \mathrm{Pu}) \mathrm{N}$ fuel pellets, containing $15 \% \mathrm{Pu}$ for LMFBR.

The EGT and EGU processes and facility at KfK, Juelich and the IGU method and set-up at BARC were utilized for preparation of hydrated gel-microspheres of oxide and oxide-carbon mixture, starting from the nitrate solutions of $\mathrm{U}, \mathrm{Pu}$ and $\mathrm{Th}$. For $\mathrm{UO}_{2}$ and $(\mathrm{U}, \mathrm{Pu}) \mathrm{O}_{2}$, the SGMP process was combined with low temperature oxidative sintering (LTS) for economic production of fuel pellets, conforming to PHWR, LWR and LMFBR fuels specifications.

Table 3. Specific surface area (SSA) of hydrated gel-microspheres and press-feed microspheres of oxide, carbide and nitride.

\begin{tabular}{|c|c|c|c|c|c|}
\hline \multirow[b]{2}{*}{$\begin{array}{l}\text { Gel-microspheres } \\
\left(\text { (SSA: } \mathrm{m}^{2} / \mathrm{g} \text { ) }\right.\end{array}$} & \multirow[b]{2}{*}{$\begin{array}{l}\text { Gelation } \\
\text { process }\end{array}$} & \multicolumn{4}{|c|}{ Microspheres after calcination/carbothermic synthesis } \\
\hline & & Composition & Type & $\begin{array}{c}\mathrm{SSA} \\
\left(\mathrm{m}^{2} / \mathrm{g}\right)\end{array}$ & $\begin{array}{c}\text { Calcination/ } \\
\text { carbothermic } \\
\text { synthesis } \\
\text { temperature } \\
\left({ }^{\circ} \mathrm{C}\right)\end{array}$ \\
\hline $\begin{array}{l}\mathrm{ThO}_{2}+\mathrm{UO}_{3}+\mathrm{C}(170 \cdot 0) \\
\mathrm{UO}_{3}+\mathrm{C} \\
\mathrm{UO}_{3}+\mathrm{C} \\
\mathrm{UO}_{3}+\mathrm{PuO}_{2}+\mathrm{C}(\mathbf{( 8 9 \cdot 0 )}) \\
\mathrm{UO}_{3}+\mathrm{PuO}_{2} \\
\mathrm{UO}_{3}+\mathrm{PuO}_{2}+\mathrm{C}(56 \cdot 3) \\
\mathrm{UO}_{3}+\mathrm{PuO}_{2}+\mathrm{C}(59 \cdot 8)\end{array}$ & $\begin{array}{l}\text { KSA-EGT } \\
\text { KAA-EGU } \\
\text { BARC-IGU } \\
\text { BARC-IGU } \\
\text { BARC-IGU } \\
\text { BARC-IGU } \\
\text { BARC + IGU }\end{array}$ & 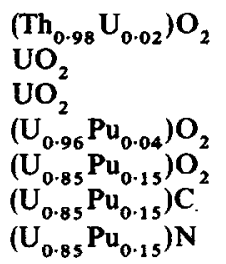 & $\begin{array}{l}\text { Porous } \\
\text { Porous } \\
\text { Porous } \\
\text { Porous } \\
\text { Porous } \\
\text { Non-porous } \\
\text { Non-porous }\end{array}$ & $\begin{array}{r}40 \cdot 00 \\
10 \cdot 00 \\
4 \cdot 45 \\
4 \cdot 25 \\
23 \cdot 00 \\
0 \cdot 14 \\
0 \cdot 20\end{array}$ & $\begin{array}{r}700 \\
700 \\
700 \\
700 \\
700 \\
1450 \\
1550\end{array}$ \\
\hline
\end{tabular}


The objective was to optimize the process parameters of SGMP route to produce either: (a) high density ( $\geqslant 94 \%$ T.D.) oxide or mixed oxide pellets, containing uniformly distributed "closed" spherical pores in the diameter range of 2-5 $\mu$, recommended for high burn-up (20,000 MWD/ton and 50,000 MWD/ton for PHWR and LWR respectively) and high integrity LWR and PHWR fuels to retain fission gas and to avoid pellet cladding interaction (PCI) failure of zircaloy cladding tube; (b) relatively low density ( $\leqslant 85 \%$ T.D.) $(\mathrm{U}, \mathrm{Pu}) \mathrm{O}_{2},(\mathrm{U}, \mathrm{Pu}) \mathrm{C}$ and $(\mathrm{U}, \mathrm{Pu}) \mathrm{N}$ fuel pellets of small grain size $(\leqslant 10 \mu)$ and containing uniformly distributed "open" pores recommended for high burn-up ( $\geqslant 1,00,000 \mathrm{MWD} /$ ton) LMFBR fuel to facilitate fission gas release and in turn reduce fuel swelling and pellet cladding mechanical interaction (PCMI) failure of stainless steel cladding tube. LMFBR fuel pins have gas plenum for accommodating $100 \%$ release of fission gas during in-pile operation.

\section{Preparation of sol-gel microspheres}

Table 3 summarizes the characteristics of hydrated gel-microspheres and (Th, $U) \mathrm{O}_{2}$, $\mathrm{UO}_{2},(\mathrm{U}, \mathrm{Pu}) \mathrm{O}_{2},(\mathrm{U}, \mathrm{Pu}) \mathrm{C}$ and $(\mathrm{U}, \mathrm{Pu}) \mathrm{N}$ microspheres prepared in the present study.

\subsection{EGT and EGU routes}

Figure 2 shows the EGT and EGU processes of KfK, West Germany, schematically.

For preparation of hydrated gel-microspheres of $\mathrm{ThO}_{2}+\mathrm{UO}_{3}$, the "sol" was prepared from thorium and uranyl nitrate feed solutions. Gaseous ammonia was fed through a hollow, rotating disperser shaft immersed in a jacketted and water-heated beaker containing $\mathrm{Th}\left(\mathrm{NO}_{3}\right)_{4}$ or mixture of $\mathrm{Th}\left(\mathrm{NO}_{3}\right)_{4}$ and $\mathrm{UO}_{2}\left(\mathrm{NO}_{3}\right)_{2}$ solutions in volume proportion of $\sim 96 \%$ and $\sim 4 \%$ respectively at $100 \pm 5^{\circ} \mathrm{C}$. Pre-neutralization

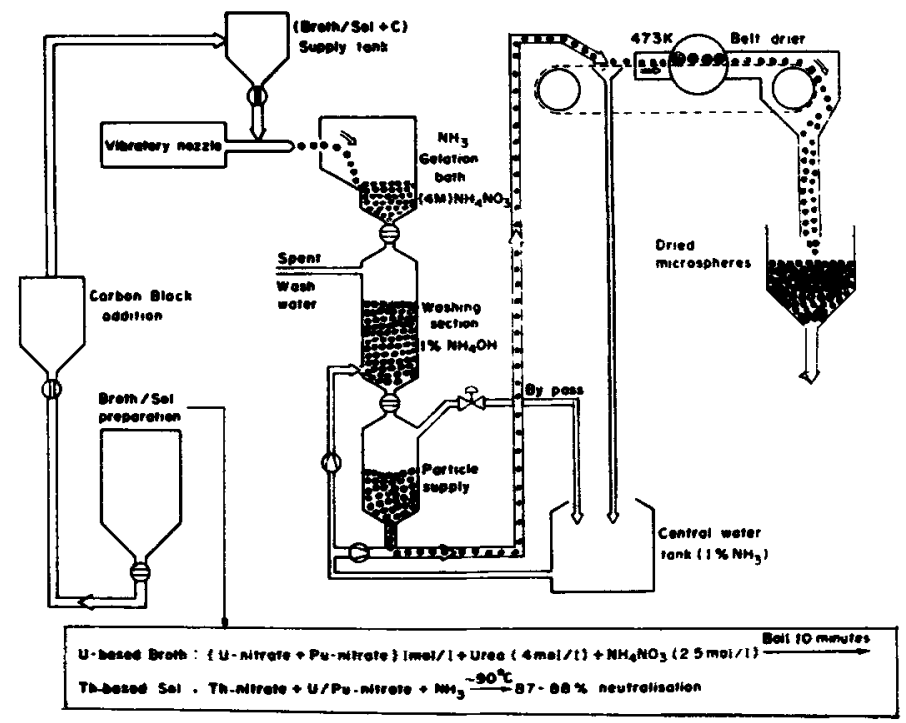

Figure 2. External gelation of uranium (EGU) and thorium (EGT) processes of Juelich, Germany for preparation of hydrated gel-microspheres of $\mathrm{ThO}_{2}+\mathrm{UO}_{3}+\mathrm{C}$ and $\mathrm{UO}_{3}+\mathrm{C}$. 
$(\sim 87 \%)$ resulted in an optimum sol of pH $3 \cdot 25-3.50$ and viscosity $3 \cdot 10^{-2}$ Pa.s. Apart from ammonia no other chemicals were needed in EGT process.

For preparation of gel-microspheres of uranium oxide via the EGU process, urea was used as a complexing agent. In addition, $\mathrm{NH}_{4} \mathrm{NO}_{3}$ was also added to keep the $\mathrm{pH}$ of solution in the range of $3 \cdot 2-3.5$ in order to have a gel-like precipitate. The optimum broth composition for EGU process consisted of a mixture of $1 \mathrm{~mol} / 1$ uranyl nitrate solution, $4 \mathrm{~mol} / 1$ urea and $2.5 \mathrm{~mol} / 1$ ammonium nitrate. The broth was boiled for $10 \mathrm{~min}$ to decompose a small fraction $(10 \%)$ of urea. $\mathrm{NH}_{3}$ thus released caused $25-30 \%$ pre-neutralization which accelerated the hardening of droplets in the subsequent gelation step. The resultant solution is clear and stable. For improved mechanical stability of the gel-droplets, $5 \mathrm{~g} / 1$ poly vinyl alcohol (PVA) was added to the broth. The EGU process could be extended for preparation of $\mathrm{UO}_{3}+\mathrm{PuO}_{2}$ microspheres containing up to $30 \% \mathrm{PuO}_{2}$.

Droplets of thorium-uranium bearing "sols" or uranium-based broth were introduced through an electromechanical vibrator with a horizontal jetting nozzle inside a containment box that housed two horizontal ammonia gas pipes and the gelation bath. Thus, the droplets passed through a curtain of $\mathrm{NH}_{3}$ gas and quickly coated themselves with a gel-skin before falling into the gelation bath. In the gelation bath the droplets gelled and settled to the bottom of the containment box. The bath composition was water with $1 \% \mathrm{NH}_{4} \mathrm{OH}$ and $4 \mathrm{~mol} \mathrm{NH}_{4} \mathrm{NO}_{3} / 1$ with $\mathrm{pH}$ close to 8 . The nozzle bore diameter, $0.6-0.8 \mathrm{~mm}$, and nozzle frequency $500-600 \mathrm{~Hz}$ led to droplet diameter between 1.2 and $1.4 \mathrm{~mm}$. The gel-microspheres containing $\mathrm{NH}_{4} \mathrm{NO}_{3}$ were transferred to a wash column containing water with $1 \% \mathrm{NH}_{3}$ to wash out the ammonium nitrate. The washed microspheres were dried in humid air on a continuous belt drier at $200^{\circ} \mathrm{C}$ for $15 \mathrm{~min}$. The gel-microspheres thus produced had excellent sphericity.

For preparation of oxide microspheres suitable for direct pelletization and sintering to high density oxide or mixed oxide pellets for PHWR and LWR the following modifications were made in EGT and EGU processes:

(i) thorium and uranium nitrate feed solutions of lower concentration were used (molarity: 0.8 to 1.2 ),

(ii) $1 \mathrm{w} / \mathrm{o}$ calcium nitrate was added to thorium nitrate feed solution to have $0.2-0.4 \mathrm{wt} \% \mathrm{CaO}$ "sintering aid" in calcined ( $\mathrm{Th}, \mathrm{U}) \mathrm{O}_{2}$ microspheres,

(iii) $0.05 \mathrm{w} / \mathrm{o} \mathrm{TiO}_{2}$ powder was admixed to some batches of uranium nitrate and mixed uranium plutonium nitrate solution for obtaining $\mathrm{UO}_{2}$ and $(\mathrm{U}, \mathrm{Pu}) \mathrm{O}_{2}$ pellets of large grain size, and

(iv) $30 \mathrm{~g}$ carbon black "pore former" per mol of Th and U was added to sol or broth prior to gelation for obtaining "porous" oxide or mixed oxide microspheres after air-calcination of gel-microspheres at $700^{\circ} \mathrm{C}$.

\subsection{IGU process}

In IGU process (figure 3), nitrate solutions of $\mathrm{U}$ and $\mathrm{Pu}$ were mixed with gelation agents, namely HMTA and urea and cooled to $0^{\circ} \mathrm{C}$. The gelation agents are minimized by using an acid-deficient uranyl nitrate solution. The solution was dispersed into droplets of required size and gelled in water immiscible organic bath, usually silicon oil at $90^{\circ} \mathrm{C}$. At this temperature, HMTA decomposed and supplied ammonia to the 


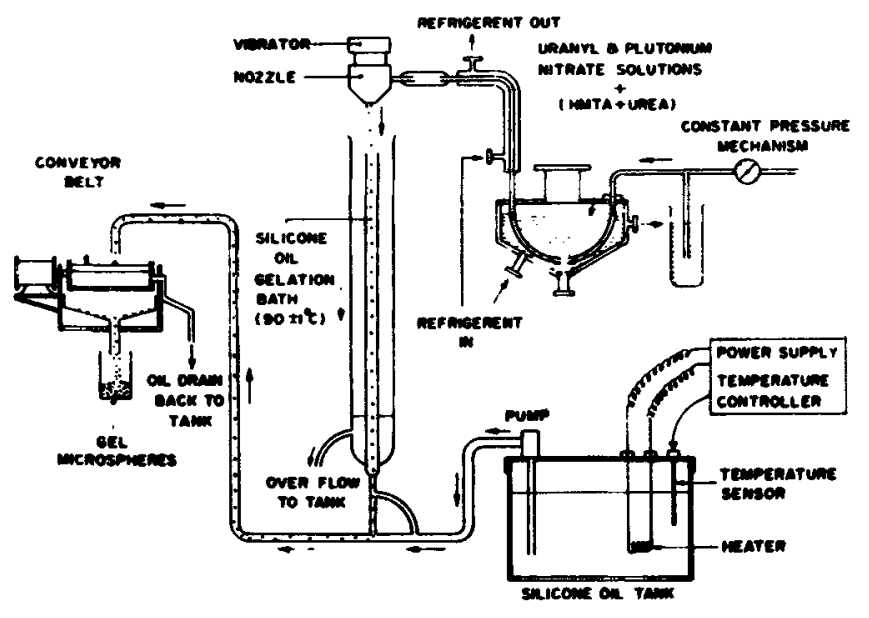

Figure 3. Internal gelation of uranium (IGU) process of BARC, Bombay, India for preparation of hydrated gel-microspheres of $\mathrm{UO}_{3}+\mathrm{C}, \mathrm{UO}_{3}+\mathrm{PuO}_{2}$ and $\mathrm{UO}_{3}+\mathrm{PuO}_{2}+\mathrm{C}$.

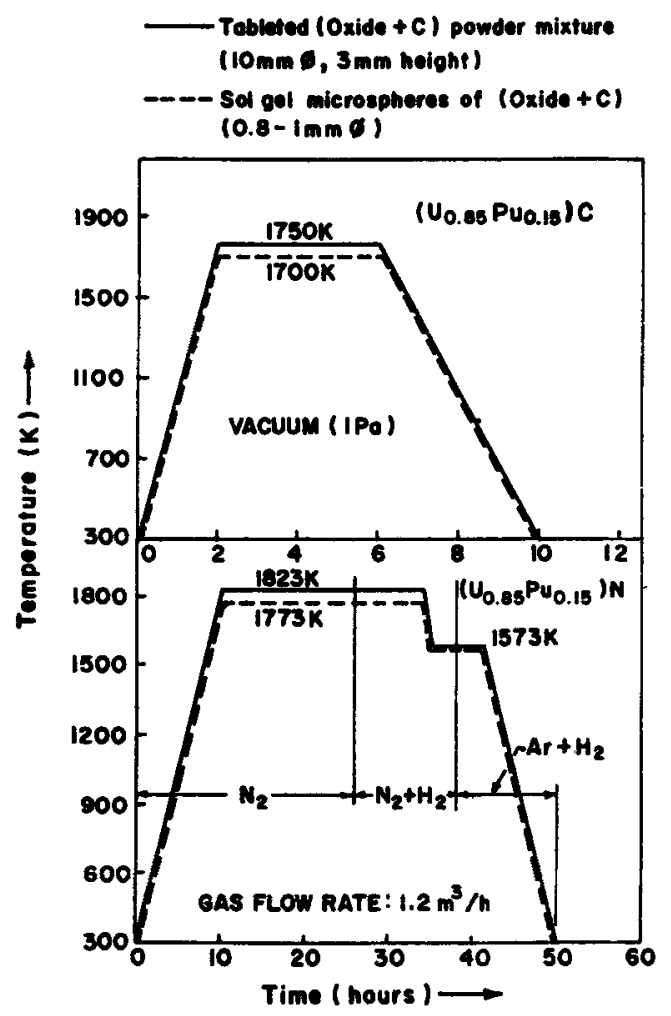

Figure 4. Temperature-atmosphere and duration for carbothermic synthesis of $\left(\mathrm{U}_{0.85} \mathrm{Pu}_{0.15}\right) \mathrm{C}$ and $\left(\mathrm{U}_{0.85} \mathrm{Pu}_{0.15}\right) \mathrm{N}$ clinkers and microspheres. 
system resulting in conversion of uranyl-urea complexes into uranyl-hydro complexes followed by precipitation of $\mathrm{UO}_{3}$ and $\mathrm{UO}_{3}-\mathrm{PuO}_{2}$ hydrates. The gel-microspheres were washed first with $\mathrm{CCl}_{4}$ to remove silicon oil and later with $\mathrm{NH}_{4} \mathrm{OH}(3 \mathrm{M})$ solution for removing $\mathrm{NH}_{4} \mathrm{NO}_{3}$ and dried in batch furnace at $200^{\circ} \mathrm{C}$ for several hours.

The modifications made in EGT and EGU processes, for obtaining microspheres suitable for pelletization, were also incorporated in IGU process. Accordingly, uranium and plutonium solutions of low molarity $(0.8-1 \cdot 2)$ were used and carbon black pore former was added to solution for preparation of porous $\mathrm{UO}_{2}$ and $(\mathrm{U}, \mathrm{Pu}) \mathrm{O}_{2}$ microspheres for fabrication of high density $\mathrm{UO}_{2}$ and $(\mathrm{U}, \mathrm{Pu}) \mathrm{O}_{2}$ pellets for use in $\mathrm{LWR}$ and PHWR.

For fabrication of relatively low density $(\mathrm{U}, \mathrm{Pu}) \mathrm{O}_{2}$ fuels for LMFBR non-porous microspheres are desirable. Hence, carbon black pore former was not added for oxide. However, for preparation of $(\mathrm{U}, \mathrm{Pu}) \mathrm{C}$ and $(\mathrm{U}, \mathrm{Pu}) \mathrm{N}$ microspheres containing $15 \%$ $\mathrm{Pu}$ for LMFBR, carbon black was added to the nitrate + urea + HMTA solution prior to gelation according to the stoichiometry of the following chemical relation:

$$
\begin{aligned}
& 0.85 \mathrm{UO}_{2}+0.15 \mathrm{PuO}_{2}+3 \mathrm{C}---\left(\mathrm{U}_{0.85} \mathrm{Pu}_{0 \cdot 15}\right) \mathrm{C}+2 \mathrm{CO} \\
& 0.85 \mathrm{UO}_{2}+0.15 \mathrm{PuO}_{2}+2 \mathrm{C}+1 / 2 \mathrm{~N}_{2}--\left(\mathrm{U}_{0.85} \mathrm{Pu}_{0 \cdot 15}\right) \mathrm{N}+2 \mathrm{CO}
\end{aligned}
$$

Figure 4 shows the time-temperature profile and atmosphere during carbothermic synthesis of $(\mathrm{U}, \mathrm{Pu}) \mathrm{C}$ and $(\mathrm{U}, \mathrm{Pu}) \mathrm{N}$ microspheres.

\section{Sol-gel microsphere pelletization (SGMP) process}

Figure 5 summarizes the important steps in SGMP process (Ganguly 1990), highlighting preparation of porous $\mathrm{UO}_{2},(\mathrm{U}, \mathrm{Pu}) \mathrm{O}_{2},(\mathrm{Th}, \mathrm{U}) \mathrm{O}_{2}$, microspheres for high density oxide or mixed oxide pellets for PHWR or LWR and non-porous $(\mathrm{U}, \mathrm{Pu}) \mathrm{O}_{2},(\mathrm{U}, \mathrm{Pu}) \mathrm{C}$ and $(\mathrm{U}, \mathrm{Pu}) \mathrm{N}$ microspheres for relatively low density pellets for LMFBR.

\section{$3.1(\mathrm{Th}, \mathrm{U}) \mathrm{O}_{2}, \mathrm{UO}_{2}$ and $(\mathrm{U}, \mathrm{Pu}) \mathrm{O}_{2}$ pellets for $\mathrm{PHWR}$}

For preparation of high density $(\mathrm{Th}, \mathrm{U}) \mathrm{O}_{2}, \mathrm{UO}_{2}$ and $(\mathrm{U}, \mathrm{Pu}) \mathrm{O}_{2}$ pellets $(\leqslant 4 \%$ fissible materials) for PHWR, porous microspheres were used as feed material for pelletization and sintering (Ganguly et al 1986; Zimmer et al 1988; Ganguly et al 1989). The porous microspheres were soft, could be directly pelletized at $350 \mathrm{MPa}$ to pellets of green density $\sim 50 \%$ T.D. and be sintered to high density pellets.

For $\mathrm{UO}_{2}$ and $(\mathrm{U}, \mathrm{Pu}) \mathrm{O}_{2}$, both high temperature $\left(1650^{\circ} \mathrm{C}, 4 \mathrm{~h}\right)$ reductive $(\mathrm{Ar}+8 \%$ $\mathrm{H}_{2}$ ) sintering (HTS) and low temperature $\left(1200^{\circ} \mathrm{C}, 1 \mathrm{~h}\right)$ oxidative sintering (LTS) in $\mathrm{CO}_{2}$ or $\mathrm{N}_{2}+$ air atmosphere containing $1000 \mathrm{ppm}$ oxygen were successful for obtaining high density sintered pellets (Ganguly and Basak 1991). Figure 6 shows some representative microstructure of sintered pellets. SEM photographs clearly depict uniform distribution of closed spherical porosity in the size range of $2-5 \mathrm{~mm}$ which was also confirmed by quantitative image analysis. The uniform distribution of 2-5 diameter spherical porosity contributed to improved thermal conductivity of oxide pellets by more than $10 \%$ (Figure 7 ) compared to pellets of equivalent density prepared by "powder-pellet" route.

Several kilograms of high density $\mathrm{UO}_{2}$ pellets have recently been prepared at BARC by SGMP-LTS route. These pellets have been utilized for constituting a 19-pin 


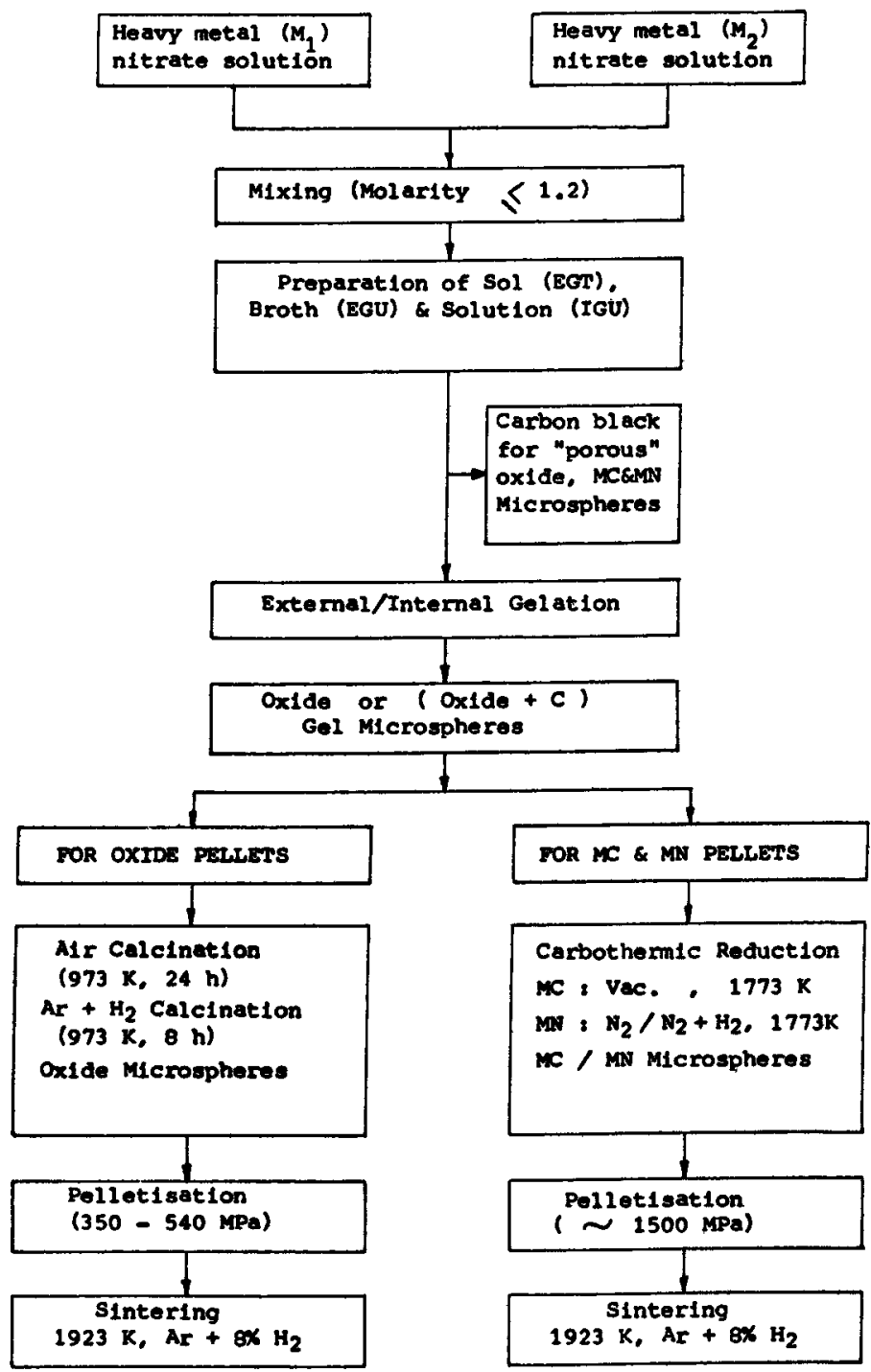

Figure 5. Flowsheet for sol-gel microsphere pelletization (SGMP) of oxide, carbide and nitride fuels of $\mathrm{U}, \mathrm{Pu}$ and $\mathrm{Th}$.

zircaloy clad fuel bundle (containing $15 \mathrm{~kg} \mathrm{UO}_{2}$ pellets) which is undergoing in-pile testing in a coolant channel of one of the $220 \mathrm{MWe}$ PHWRs at the Madras Atomic Power Station.

\section{$3.2(U, P u) O_{2},(U, P u) C$ and $(U, P u) N$ pellets for $L M F B R$}

The non-porous mixed uranium-plutonium oxide, monocarbide and mononitride microspheres (Ganguly et al 1987, 1991) were extremely hard and could be compacted only at high compaction pressure ( $\sim 550 \mathrm{MPa}$ for oxide and $1000-1500 \mathrm{MPa}$ for 


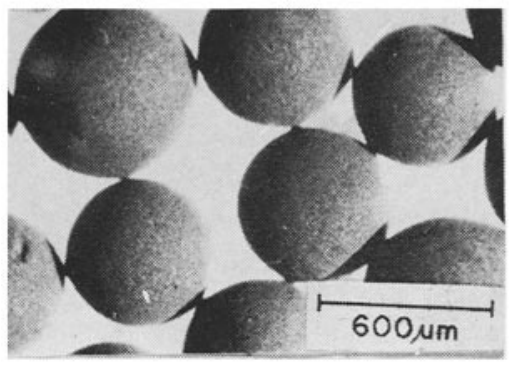

Calcined porous $\mathrm{UO}_{2}$ microspheres $\left(\mathrm{UO}_{3}+\right.$ C gel microspheres: IGU process)

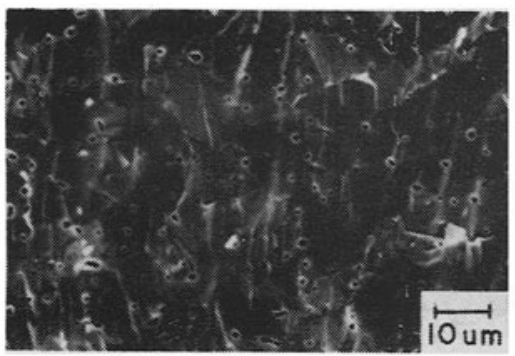

SEM pictures of sintered $\mathrm{UO}_{2}$ pellet showing uniform pore distribution (gel microspheres: EGU process)

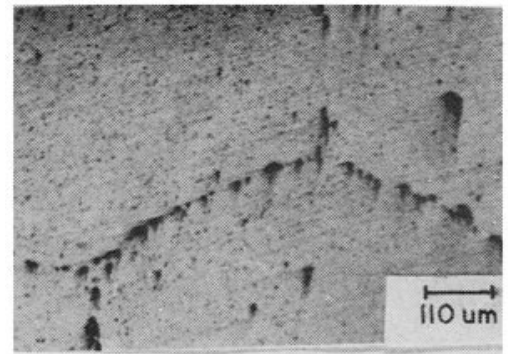

Microstructure of sintered $(\mathrm{U}, \mathrm{Pu}) \mathrm{O}_{2}$ pellets $(\sim 15 \%$ Pu) prepared by SGMP.LTS (gel microspheres: IGU process)

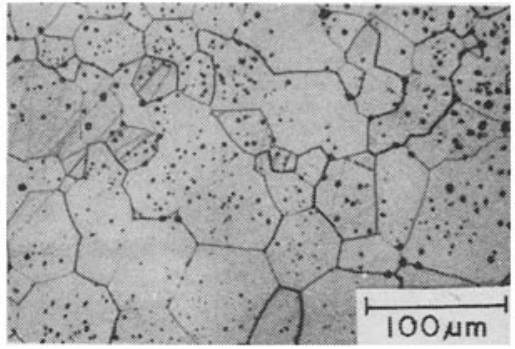

Microstructure of sintered $\mathrm{UO}_{2}$ pellet $\left(\mathrm{TiO}_{2}\right.$ doped) with large grain size.

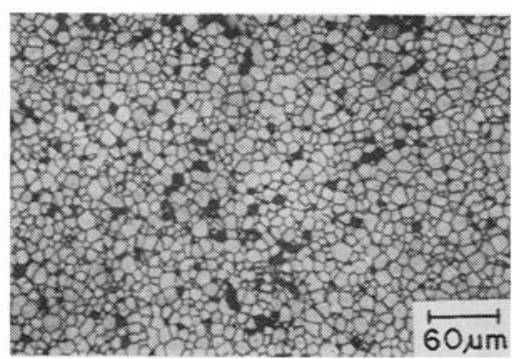

Microstructure of sintered (Th, $\mathrm{U}) \mathrm{O}_{2}$ pellets (gel microspheres: EGT process)

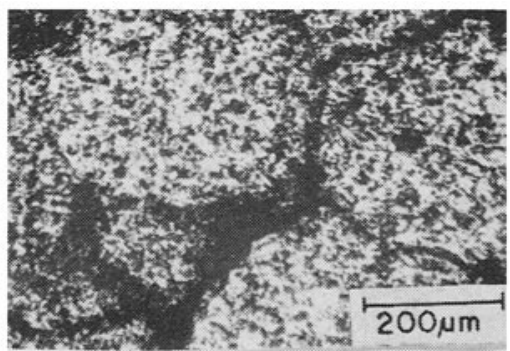

Microstructure of sintered (U, Pu)N pellets $(\sim 15 \% \mathrm{Pu})$

(gel microsphere: IGU process)

Figure 6. Representative microstructure of sintered $\mathrm{UO}_{2},(\mathrm{Th}, \mathrm{U}) \mathrm{O}_{2},(\mathrm{U}, \mathrm{Pu}) \mathrm{O}_{2}$ and $(\mathrm{U}, \mathrm{Pu}) \mathrm{N}$ pellets prepared by SGMP route at BARC, Bombay, India.

monocarbide and mononitride). The pellets after sintering to $1650^{\circ} \mathrm{C}$ for $4 \mathrm{~h}$ in $\mathrm{Ar}+8 \% \mathrm{H}_{2}$ led to sintered pellets of relatively low density ( $\leqslant 85 \%$ T.D.) with "blackberry", "open" pore microstructure as shown in figure 6. For $(\mathrm{U}, \mathrm{Pu}) \mathrm{O}_{2}$, both SGMP-LTS and SGMP-HTS led to similar pellet density and microstructure. However, the grain size of SGMP-LTS derived $(\mathrm{U}, \mathrm{Pu}) \mathrm{O}_{2}$ pellets was finer $(\leqslant 5 \mu)$. 

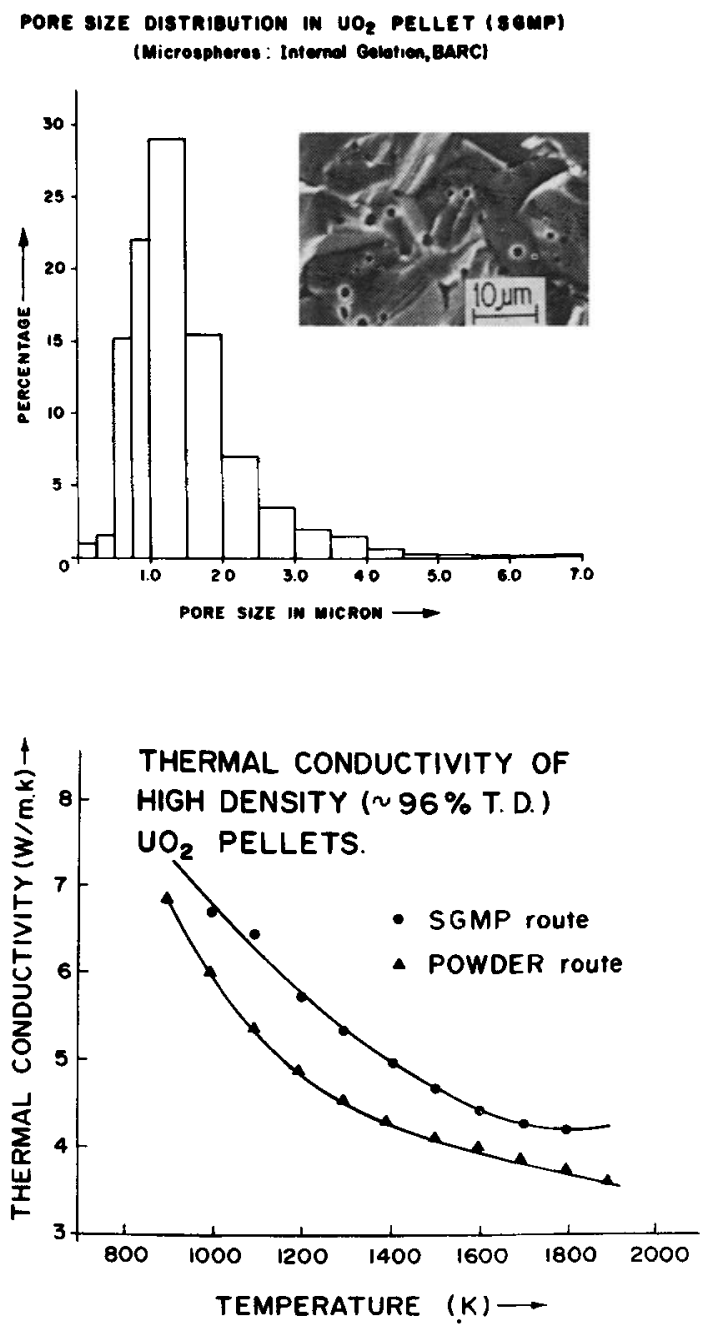

Figure 7. Pore size distribution in high density $\mathrm{UO}_{2}$ pellet prepared by SGMP route and intercomparison of thermal conductivity of $\mathrm{UO}_{2}$ pellets of similar density prepared by SGMP and powder-pellet route.

\section{Summary and conclusion}

(i) The viability of SGMP route shown schematically in figure 8 for fabrication of oxide, monocarbide and mononitride fuel pellets of controlled density and microstructure has been established. The SGMP route is an attractive alternative to powderpellet route for remote, automated and economic production of ceramic nuclear fuels, in general, and highly radiotoxic $\mathrm{Pu}$ and ${ }^{233} \mathrm{U}$ bearing oxide, carbide and nitride fuel pellets in particular.

(ii) For high density ( $\geqslant 94 \%$ T.D.) oxide or mixed oxide pellets for water-cooled reactors, porous microspheres should be used as feed material. For this carbon black pore former should be added to sol or broth prior to gelation and later removed by 


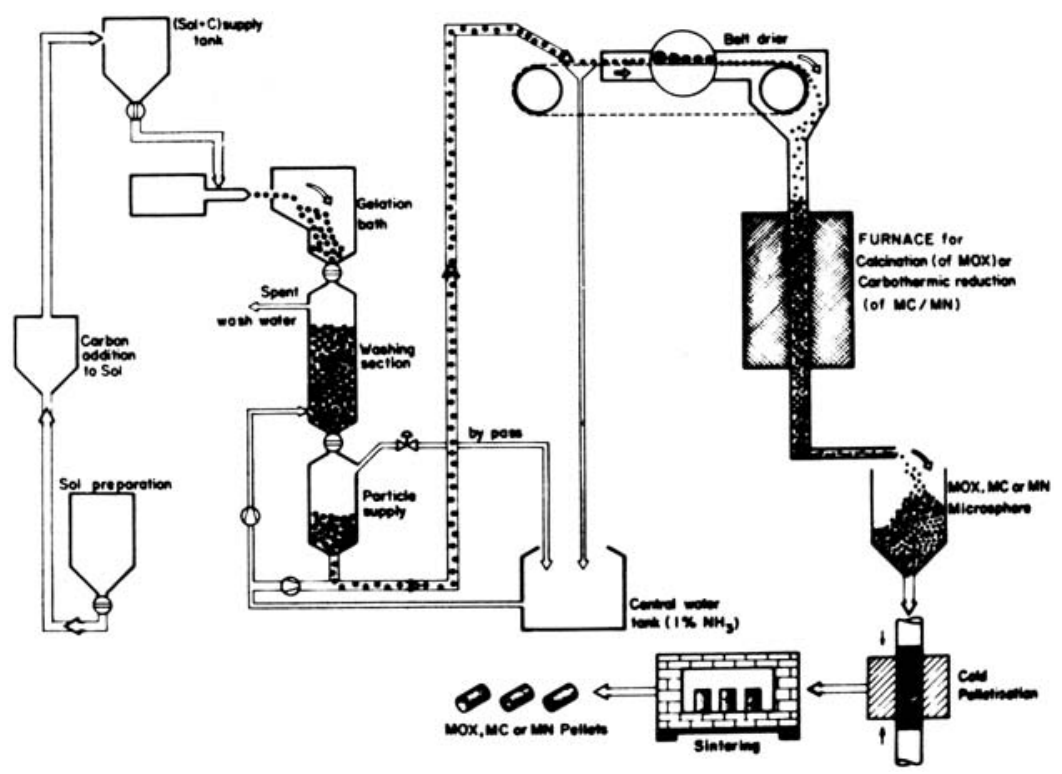

Figure 8. Schematic diagram of SGMP process developed at. BARC, Bombay, India for preparation of high density ( $\geqslant 96 \%$ T.D.) $\mathrm{UO}_{2},(\mathrm{U}, \mathrm{Pu}) \mathrm{O}_{2}$ or $(\mathrm{Th}, \mathrm{U}) \mathrm{O}_{2}$ fuel pellets for $\mathrm{LWR}$ and PHWR or low density ( $\leqslant 85 \%$ T.D.) $(\mathrm{U}, \mathrm{Pu}) \mathrm{O}_{2}(\mathrm{U}, \mathrm{Pu}) \mathrm{C}$ or $(\mathrm{U}, \mathrm{Pu}) \mathrm{N}$ fuel pellets for LMFBR.

controlled air-calcination at around $700^{\circ} \mathrm{C}$. The porous microspheres are soft and get crushed and lose their individual identity during pelletization. Thus, closed spherical pores of $2-5 \mu$ are obtained in high density sintered pellets.

The combined SGMP-LTS process has been successfully employed for fabrication of high density $\mathrm{UO}_{2}$ and $(\mathrm{U}, \mathrm{Pu}) \mathrm{O}_{2}$ fuel pellets for PHWR application thus minimizing "radiotoxic dust hazard" and electrical energy and furnace gas requirement during sintering.

(iv) For relatively low density mixed uranium-plutonium oxide, monocarbide and mononitride fuels non-porous microspheres are ideal feed materials. These microspheres are hard and need higher compaction pressure for pelletization. The sintered pellets prepared from non-porous microspheres have a typical "blackberry" structure with open pore because the microspheres retain their individual identity even after compaction at high pressure.

\section{Acknowledgement}

The author is grateful to his colleagues in the Institute of Chemical Technology, KfK (Nuclear Research Centre), Juelich, Germany and the Radiometallurgy and Fuel Chemistry Divisions of Bhabha Atomic Research Centre, Bombay, India for their all round cooperation and support in carrying out the investigations on sol-gel microsphere pelletization process. 


\section{References}

Ferguson D E, Dean O C and Haas P A 1961 CEND-153 (USA: Oak Ridge National Laboratory) 1

Ganguly $\mathrm{C} 1980$ Studies on preparation and sintering of $(U, P u) C,(U, P u) N$ and $(U, P u)(C N)$ pellets, Ph.D. thesis, University of Calcutta, Calcutta

Ganguly C 1990a Indian J. Technol. 28296

Ganguly C 1990b Metals, Mater. Process. 1253

Ganguly C, Langer H, Zimmer E and Merz E 1986 Nucl. Technol. 15284

Ganguly C, Linke U and Kaiser E 1987 Metallography 201

Ganguly C, Basak U, Vaidya V N, Sood D D and Roy P R 1989 Proc. Ind inter. conf. on CANDU fuel, Chalk River, Canada, pp $108-124$

Ganguly C and Basak U $1991 \mathrm{~J}$. Nucl. Mater. 178179

Ganguly C, Hegde P V and Sengupta A K 1991 J. Nucl. Mater. 178234

IAEA 1974 Proc. IAEA panel on sol-gel processes, Vienna, IAEA-161

Matzke Hj 1986 Science of advanced LMFBR fuels (North Holland: Elsevier Science publications)

Naefe P and Zimmer E 1979 Nucl. Technol. 42163

Ringel H D and Zimmer E 1979 Nucl. Technol. 45287

Vaidya V N, Mukherjee S, Joshi J K, Kamat R V and Sood D D 1987 J. Nucl. Mater. 148324

Zimmer E, Ganguly C, Borchardt J and Langer H 1988 J. Nucl. Mater. 152169 